\title{
Molecular Characterization of Bacteria Isolated from Some Seafoods in Nembe Community, Bayelsa State, Nigeria
}

\author{
Justice-Alucho, C. H. ${ }^{*}{ }^{*}$ Mike-Anosike, E. E. ${ }^{2} \&$ Braide, W. ${ }^{3}$ \\ ${ }^{1-3}$ Department of Microbiology, Federal University of Technology, Owerri, Imo State, Nigeria. \\ Email: chinwe.justice-alucho@futo.edu.ng ${ }^{{ }^{*}}$
}

DOI: http://doi.org/10.38177/ajast.2021.5306

Copyright: () 2021 Justice-Alucho, C. H. et al. This is an open access article distributed under the terms of the Creative Commons Attribution License, which permits unrestricted use, distribution, and reproduction in any medium, provided the original author and source are credited.

\section{ABSTRACT}

The quest for better food quality has invariably increased cases of food-borne infections which in turn contribute to the problem of antibiotic resistance as a result of drug abuse. This study is aimed at characterizing bacterial isolates from some seafood sold in Nembe, Bayelsa State, Nigeria A total of 200 fresh seafood samples (crab, shrimp, oyster and periwinkle) were collected randomly from Nembe, Bayelsa State. Isolates were obtained using the conventional microbiological methods and the pure cultures were screened by gram staining and biochemical test for preliminary identification. Isolates were further characterized for 16SrRNA using Polymerase Chain Reaction and Sequencing. The most dominant species isolated were Staphylococcus gallinarum 27(22.5\%), Vibrio rotiferanus 17(14.2\%), Vibrio parahaemolyticus 48(40\%), Klebsiella aerogenes $10(8.3 \%)$ and Klebsiella quasipneumoniae $18(15 \%)$. Analysis of variance (ANOVA) by single factor was done to determine the variation in colony counts of isolates from the different seafood samples and $\mathrm{P}$ value was $>0.05$ indicating that there is no significant difference in colony counts among the different sea foods. The presence of these bacterial species in these seafood samples renders the food unsafe for consumption. Adequate handling as well as proper cooking of seafood before consumption is highly recommended so as to reduce the incidence of food-borne infections.

Keywords: Sea foods, Molecular characterization, Bacterial isolates.

\section{Introduction}

The quest for better food quality has led to an exponential increase in the consumption of seafood because of the nutritional composition. Increased consumption of these foods without proper handling and preparation has led to an increase in the incidence of food borne infection and food poisoning thus posing such high public health risk (Adeleye et al., 2010). There is therefore a need to ensure food safety at all levels by eliminating every source of contamination in these sea foods.

Bacteria of the genus Vibrio, Klebsiella and Staphylococcus have been implicated in seafood (Dib et al., 2014). Vibrio species inhabit the estuarine/coastal regions and have been implicated in raw or undercooked seafood as well as account for a significant proportion of human infections such as gastroenteritis which is usually associated with consumption of raw or undercooked seafood, wound infections, septicemia and ear infections (Adeleye et al., 2010). In Nigeria for instance, V. parahaemolyticus associated with gastroenteritis due to consumption of contaminated seafood has been reported (Adeleye et al., 2010). They are widely distributed worldwide in seawater and are found commonly in association with resident aquatic organisms (Arungiri et al., 2016).

Vibrio species are found in sea foods such as shell fish, bivalves mollusks, oysters, shrimps and other benthic animals and have been implicated in a number of gastro enteric diseases and pose a considerable public health threat and also as agent of sporadic and epidemic food borne infections associated with consumption of undercooked or raw sea foods (Arungiri et al., 2016).

The Vibrio pathogenic species produce various virulence factors including enterotoxin, haemolysin, cytotoxin, protease, lipase, phospholipase, siderophore, adhesive factor and haemagglutinins (Zhang and Austin, 2005).The 
pathogenicity of $V$. parahaemolyticus is associated with the production of thermostable direct haemolysis and TDH-related hemolysin encoded by the $t d h$ and $t r h$ genes respectively, and these are responsible for the haemolysis of human red blood cells. It also possesses a thermolabile hemolysin encoded by the $t$ lh genes (Zhang and Austin, 2005). These bacteria have been recognized as the main agents causing food borne diseases in many countries including Asia, United States, France, Mexico, Peru and Chile (Cabanillas et al., 2006). Due to the increase in the consumption of sea foods worldwide there has been a drastic increase in food borne infection which in turn has led to the increase in gastro enteric diseases in humans (Cabanillas et al., 2006). Sporadic cases of cholera have been reported in Nigeria as well as gastroenteritis caused by $V$. parahemoluticus resulting from the consumption of raw and undercooked seafood (Cabanillas et al., 2006).

Staphylococcus species are usually associated with the skin and mucous membrane microflora of humans and animal such as chicken skin (Tibra et al., 2010). They are gram positive, mesophilic, oxidase negative cocci organisms that have been implicated in several clinical and environmental samples (Tibra et al., 2010). The diseases caused by staphylococcus species ranges from acute septicemia to osteomyelitis in poultry (Xu et al., 2018). Staphylococcus gallinarum are usually isolated from chicken skin but have also been isolated from seafood (Tibra et al., 2010). Staphylococcus species possess virulence factors such as enterotoxin, coagulase, hemolysins, toxins etc (Kérouanton et al., 2007). Food poisoning arising from ingesting food infected by Staphylococcal enterotoxins is usually of high risk due to the presence of Staphylococcal enterotoxins (Omoe et al., 2005). Klebsiella species have been implicated in both human and animal samples where they play roles as pathogens widely distributed in the environment (Brisse et al., 2009; Shon et al., 2013). They are gram negative rod shaped oxidase negative bacteria that have been implicated in so many clinical infections such as pneumonia, wound infection, meningitis, urinary tract infections, nosocomial infections, etc (Holt et al., 2015). The pathogenicity factors of Klebsiella are capsules or lipopolysachharide and are considered potential candidate for vaccination that will serve as infection immunological control measures (Holt et al., 2015). Different species of Klebsiella are Klebsiella pneumoniae, Klesiella aerogenes, Klebsiella quasipneumoniae, Klebsiella varicola etc. (Brisse \& Verhoef, 2001).

The people of Nembe live around the river banks and are known majorly for fishing as an occupation. There is constant discharge of domestic, agricultural and industrial sewage into the water bodies where these seafoods are harvested from and thus poses a high risk to the community who consume these foods undercooked or even raw.

Benthic organisms otherwise called benthos are community of organisms that live in, on or near the sea bed called the benthic zone. Benthic organisms such as sea stars, oysters, clams, sea cucumbers, brittle stars and sea anemones serve as important sources of food due to their nutritional properties (Ryan, 2007).

This study is aimed at screening seafood samples obtained from Bayelsa for the presence of bacterial species.

\section{Methodology}

\section{Determination of ample size}

Using a single proportion formula, the sample size is calculated thus: 
$\mathrm{n}=\mathrm{Z}^{2} \mathrm{pq} / \mathrm{d}^{2}$

Where: $\mathrm{n}=$ desired sample size, when population is more than $10,000, \mathrm{Z}=$ Critical value at $90 \%$ or 1.64 confidence interval, $\mathrm{p}=$ Prevalence or population with the desired attribute pegged at $25 \%$ i.e 0.25

$\mathrm{q}=1-\mathrm{p}$

$\mathrm{d}=$ degree of accuracy usually set at 0.05

Hence, $\mathrm{Z}=1.64, \mathrm{p}=0.25, \mathrm{q}=0.75, \mathrm{~d}=0.05, \mathrm{n}=1.64^{2} \times 0.25 \times 0.75 / 0.052 \mathrm{n}=0.5043 / 0.0025 \mathrm{n}=201.72 \mathrm{n} \approx 200$

\section{Sample collection}

Two hundred (200) seafood samples comprising of periwinkle, crab, oyster and shrimps were purchased from fisher men at the Nembe River, Bayelsa State, Nigeria. The samples were collected in sterile containers and transported in ice chest to the Microbiology Laboratory, Federal University of Technology, Owerri.

\section{Sample preparation}

Each of the samples collected were macerated using a sterile stomacher blender to increase surface area to volume ratio and to obtain a homogenous state of the sample. The samples were serially diluted (10 folds dilution) using peptone water and an aliquot $(0.1 \mathrm{ml})$ of the diluted sample was collected and inoculated onto the already prepared sterile Thio-Citrate Bile salt Sucrose (TCBS) agar plates.

\section{Inoculation and isolation}

One-tenth milliliter $(0.1 \mathrm{ml})$ of the aliquot from the required dilution factor $\left(10^{4}\right)$ was aseptically inoculated onto the freshly prepared and surface dried medium using a sterilized pipette. An L-shaped spreader was used to evenly distribute the inoculums round the surface of the agar plate so as to obtain discrete and countable colonies after incubation. The agar plate was allowed to dry after which it was incubated at $35^{\circ} \mathrm{C}$ for $24 \mathrm{~h}$. The results of the colonies grown were recorded.

\section{Phenotypic identification}

One hundred and twenty (120) bacterial isolates were phenotypically identified by subjecting them to standard microscopic and biochemical test according to the method of Cheesbrough (2006).

\section{Molecular analysis}

\section{DNA Extraction (Boiling method)}

Five milliliters ( $5 \mathrm{ml}$ ) of an overnight broth culture of the bacterial isolate in Luria Bertani (LB) was spun at 14000 rpm for $3 \mathrm{~min}$. The cells were re-suspended in $500 \mu \mathrm{l}$ of normal saline and heated at $95^{\circ} \mathrm{C}$ for $20 \mathrm{~min}$. The heated bacterial suspension was cooled on ice and spun for $3 \mathrm{~min}$ at $14000 \mathrm{rpm}$. The supernatant containing the DNA was moved to a $1.5 \mathrm{ml}$ microcentrifuge tube and stored at $-20^{\circ} \mathrm{C}$ for other down-stream reactions (Tamura et al., 2013).

\section{DNA quantification}

The extracted genomic DNA was quantified using the Nanodrop 1000 spectrophotometer. The software of the equipment was launched by double clicking on the Nanodrop icon. The equipment was initialized with $2 \mu 1$ of 
sterile distilled water and blanked using normal saline. Two microlitres of the extracted DNA was loaded onto the lower pedestal; the upper pedestal was brought down to contact the extracted DNA on the lower pedestal. The DNA concentration was measured by clicking on the "measure" button (Tamura et al., 2013).

\section{PCR Amplification of the 16SrRNA gene (27F and 1492R)}

The 16srRNA region of the rRNA gene of the isolates were amplified using the 27F: 5'-AGAGTTTGATCMTG GCTCAG-3' and 1492R: 5'-CGGTTACCTTGTTACGACTT-3' primers on an ABI 9700 Applied Biosystems thermal cycler at a final volume of 40 microlitres for 35 cycles. The PCR mix included: the X2 Dream taq Master mix supplied by Inqaba, South Africa (taq polymerase, DNTPs, $\mathrm{MgCl}$ ), the primers at a concentration of $0.5 \mathrm{uM}$ and the extracted DNA as template. The PCR conditions were as follows: Initial denaturation, $95^{\circ} \mathrm{C}$ for 5 minutes; denaturation, $95^{\circ} \mathrm{C}$ for 30 seconds; annealing, $52^{\circ} \mathrm{C}$ for 30 seconds; extension, $72^{\circ} \mathrm{C}$ for 30 seconds for 35 cycles and final extention, $72^{\circ} \mathrm{C}$ for 5 minutes. The product was resolved on a $1 \%$ agarose gel at $130 \mathrm{~V}$ for 30 minutes and visualized on a blue light transilluminator (Tamura et al., 2013).

\section{Agarose Gel electrophoresis}

Electrophoresis of the DNA was carried out on a $1.5 \%$ agarose gel in a $0.5 \mathrm{X}$ concentration of Tris-Borate-EDTA (TBE) buffer. Agarose gel was prepared by boiling $1.5 \mathrm{~g}$ of agarose powder in 100ml of 0.5X TBE buffer. After boiling, the solution was allowed to cool and $10 \mu \mathrm{l}$ of ethidium bromide was added to the cooled agarose solution. This was poured into a casting tray with a comb placed 2 meter from the rim to form wells. The gel was allowed to set for 30 minutes and the comb was gradually removed. $5 \mu$ of the amplified PCR products were then loaded into the wells. A DNA 100 bp molecular weight marker (Solys biodyne) and a negative control (ultra pure water) were also loaded into one of the wells. The gel was thereafter electrophoresed in a horizontal tank at a constant voltage of $80 \mathrm{~V}$ for about 1 hour 30 minutes. After electrophoresis, DNA bands were visualized by ethidium bromide staining under a short wave ultraviolet light transilluminator and the photograph were taken using a digital camera (Tamura et al., 2013).

\section{Sequencing}

Sequencing was done using the BigDye Terminator kit on a 3510 ABI sequencer by Inqaba Biotechnological, Pretoria South Africa. The sequencing was done at a final volume of $10 \mu 1$, the components included $0.25 \mu 1$ BigDye ${ }^{\circledR}$ terminator v1.1/v3.1, $2.25 \mu 1$ of $5 \mathrm{x}$ BigDye sequencing buffer, $10 \mu \mathrm{M}$ Primer PCR primer, and 2-10 ng PCR template per $100 \mathrm{bp}$. The sequencing conditions were as follows; 32 cycles of $96^{\circ} \mathrm{C}$ for $10 \mathrm{~s}, 55^{\circ} \mathrm{C}$ for $5 \mathrm{~s}$ and $60^{\circ} \mathrm{C}$ for 4 mins. The corresponding sequences were identified using the online blast search at, http://blast.ncbi. nlm.nih.gov/Blast.cgi (Tamura et al., 2013).

\section{Results}

A total of 200 seafood samples were analyzed using the traditional microbiological methods. 120(60\%) pure isolates were obtained from the seafood samples and characterized. $27(22.5 \%)$ of the isolates appeared as yellow, large, flat unbrate colonies. $65(54.2 \%)$ of the pure isolates appeared as bright yellow, round, shiny small colonies as well as green large round colonies on Thio Citrate Bile Salt agar while others 28(23.3\%) were black flat colonies. 
The total variation rates of Staphylococcus sp in the different seafood samples were 9(30\%), 6(20\%), 5(16.7\%) and 7(23.3\%) in Periwinkle, Crab, Oyster and Shrimps respectively. The total variation rates of Vibrio sp in the seafood samples were 16(53.3\%), 16(53.3\%), 15(50\%) and 18(60\%) in Periwinkle, Crab, Oyster and Shrimps respectively. The total variation rates of Klebsiella sp in the seafood samples were 5(16.7\%), 8(26.7\%), 10(33.3\%) and 5(16.7\%) in Periwinkle, Crab, Oyster and Shrimps respectively. The distribution rate of the different isolates in each of the seafood samples is shown in Figure 1.0 and Tables 1-4 below.

The isolates which had similar morphological and biochemical properties were grouped into five (A, B, C, D and E) as shown on Table 6. Representative isolates were molecularly characterized by 16SrRNA gene amplification using Polymerase Chain Reaction (PCR) as well as DNA sequencing using MEGA7.0 BLASTN. The bacterial isolates identified were Staphylococcus gallinarum, Vibrio rotiferanus, Vibrio parahaemolyticus, Klebsiella aerogenes and Klebsiella quasipneumoniae. The evolutionary history (phylogenic tree) was inferred using the Neighbour-Joining method to determine the relationship between strains as shown in Figure 4.

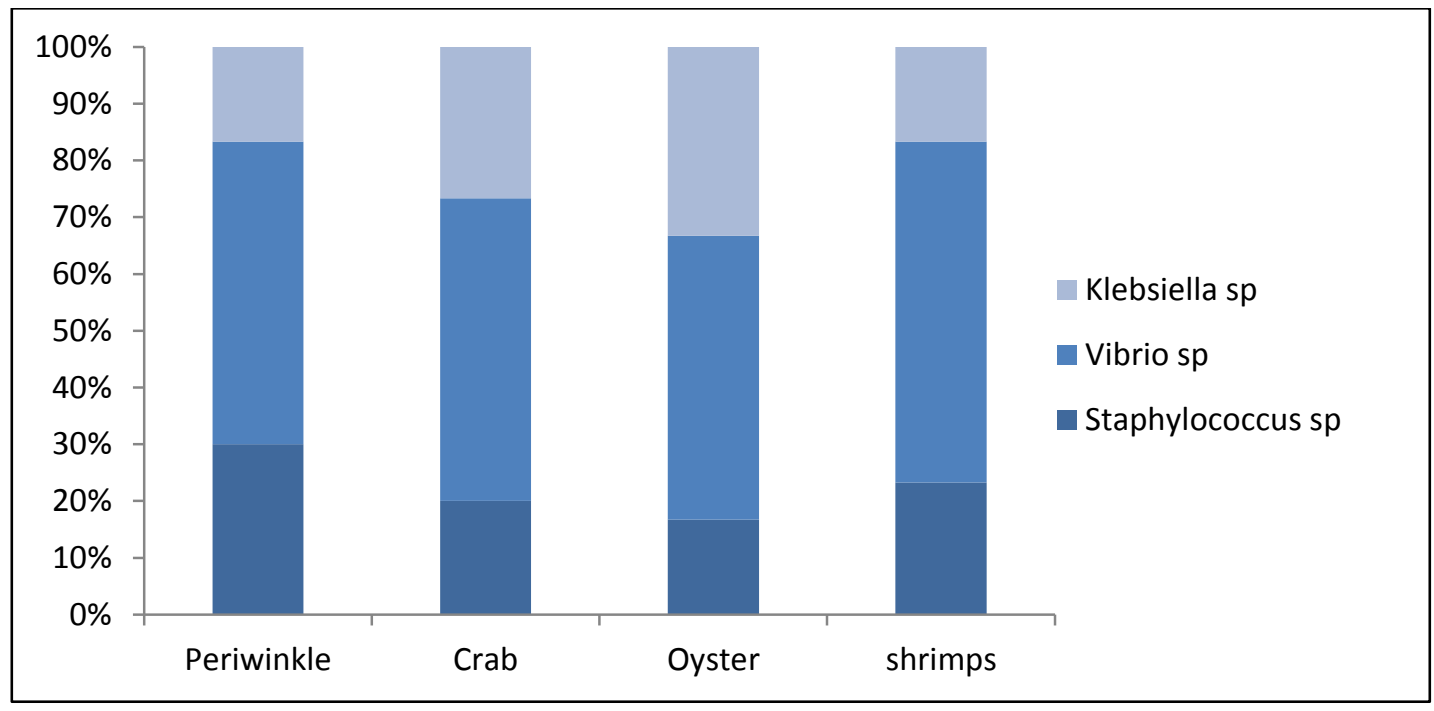

Fig.1. Distribution of bacterial isolates in the different seafood samples

\section{Bacterial Isolates as Distributed in the Different Seafood Samples}

Table 1. Distribution of Staphylococcus species in seafood samples

\begin{tabular}{lllll}
\hline $\begin{array}{l}\text { Seafood } \\
(\mathrm{n}=200)\end{array}$ & $\begin{array}{l}\text { No of Samples } \\
\text { collected }\end{array}$ & No of Isolates & $\begin{array}{l}\text { No of Staphylococcus } \\
\text { sp isolated }\end{array}$ & Prevalence $(\%)$ \\
\hline Periwinkle & 50 & 30 & 9 & 30 \\
Crab & 50 & 30 & 6 & 20 \\
Oyster & 50 & 30 & 5 & 16.7 \\
Shrimps & 50 & 30 & 7 & 23.3 \\
Total & 200 & 120 & 27 & 22.5 \\
\hline
\end{tabular}


Asian Journal of Applied Science and Technology (AJAST)

Volume 5, Issue 3, Pages 68-79, July-September 2021

Table 2. Distribution of Vibrio species in seafood samples

\begin{tabular}{lllll}
\hline $\begin{array}{l}\text { Seafood } \\
(\mathrm{n}=200)\end{array}$ & $\begin{array}{l}\text { No of Samples } \\
\text { collected }\end{array}$ & No of Isolates & $\begin{array}{l}\text { No of Vibrio sp } \\
\text { isolated }\end{array}$ & Prevalence (\%) \\
\hline Periwinkle & 50 & 30 & 16 & 53.3 \\
Crab & 50 & 30 & 16 & 53.3 \\
Oyster & 50 & 30 & 15 & 50 \\
Shrimps & 50 & 30 & 18 & 60 \\
Total & 200 & 120 & 65 & 54.2 \\
\hline
\end{tabular}

Table 3. Distribution of Klebsiella species in seafood samples

\begin{tabular}{lllll}
\hline $\begin{array}{l}\text { Seafood } \\
(\mathrm{n}=200)\end{array}$ & $\begin{array}{l}\text { No of Samples } \\
\text { collected }\end{array}$ & $\begin{array}{l}\text { No of Isolates } \\
(120)\end{array}$ & $\begin{array}{l}\text { No of Klebsiella sp } \\
\text { isolated }\end{array}$ & Prevalence (\%) \\
\hline Periwinkle & 50 & 30 & 5 & 16.7 \\
Crab & 50 & 30 & 8 & 26.7 \\
Oyster & 50 & 30 & 10 & 33.3 \\
Shrimps & 50 & 30 & 5 & 16.7 \\
Total & 200 & 120 & 28 & 23.3 \\
\hline
\end{tabular}

Table 4. Group of bacterial isolates with similar biochemical characteristics

\begin{tabular}{llllll}
\hline TEST & GROUP A & GROUP B & GROUP C & GROUP D & GROUP E \\
& 27 & 17 & 48 & 10 & 18 \\
\hline GRAM & + & - & - & - & - \\
SHAPE & Cocci & Rod & Rod & rod & Rod \\
HEMOLYSIS & - & - & + & - & - \\
CATALASE & + & - & + & + & + \\
OXIDASE & - & + & + & - & - \\
INDOLE & - & & - & - & - \\
COAGULASE & - & $\mathrm{ND}$ & $\mathrm{ND}$ & $\mathrm{ND}$ & + \\
GLUCOSE & + & + & + & + & + \\
SUCROSE & + & + & + & + & + \\
CITRATE & + & + & + & + & + \\
\hline
\end{tabular}


Asian Journal of Applied Science and Technology (AJAST)

Volume 5, Issue 3, Pages 68-79, July-September 2021

\begin{tabular}{llllll}
\hline VOGUES & ND & - & - & + & + \\
PROSKEUR & & & & & \\
$7 \% \mathrm{NaCl}$ & ND & + & + & ND & ND \\
\hline
\end{tabular}

Key: - =Negative, += Positive, ND=Not Determined

ANOVA

Table 5. One Way Anova for Seafood Samples (Single Factor)

\begin{tabular}{lllllll}
\hline Source of Variation & $S S$ & $D f$ & $M S$ & $F$ & $P$-value & F crit \\
\hline Between Groups & 0.429608 & 3 & 0.143203 & 1.743 & 0.162073 & 2.682809 \\
Within Groups & 9.53042 & 116 & 0.082159 & & & \\
Total & 9.960029 & 119 & & & & \\
\hline
\end{tabular}

Table 6. List of bacterial isolates identified by 16sRNA gene sequence analysis

\begin{tabular}{lllll}
\hline Genus & $\begin{array}{l}\text { Group of } \\
\text { isolates }\end{array}$ & $\begin{array}{l}\text { Gene bank accession } \\
\text { number }\end{array}$ & Identity (\%) & Blast value \\
\hline Staphylococcus gallinarum & $\mathrm{A}$ & MW308344 & 100 & 0.0 \\
Vibrio rotiferanus & $\mathrm{B}$ & LR702061 & 100 & 0.0 \\
Vibrio parahaemolyticus & $\mathrm{C}$ & MW142548 & 100 & 0.0 \\
Klebsiella aerogenes & $\mathrm{D}$ & MW689239 & 100 & 0.0 \\
Klebsiella quasipneumoniae & $\mathrm{E}$ & CP065841 & 100 & 0.0 \\
\hline
\end{tabular}

\section{Results from DNA Quantification}

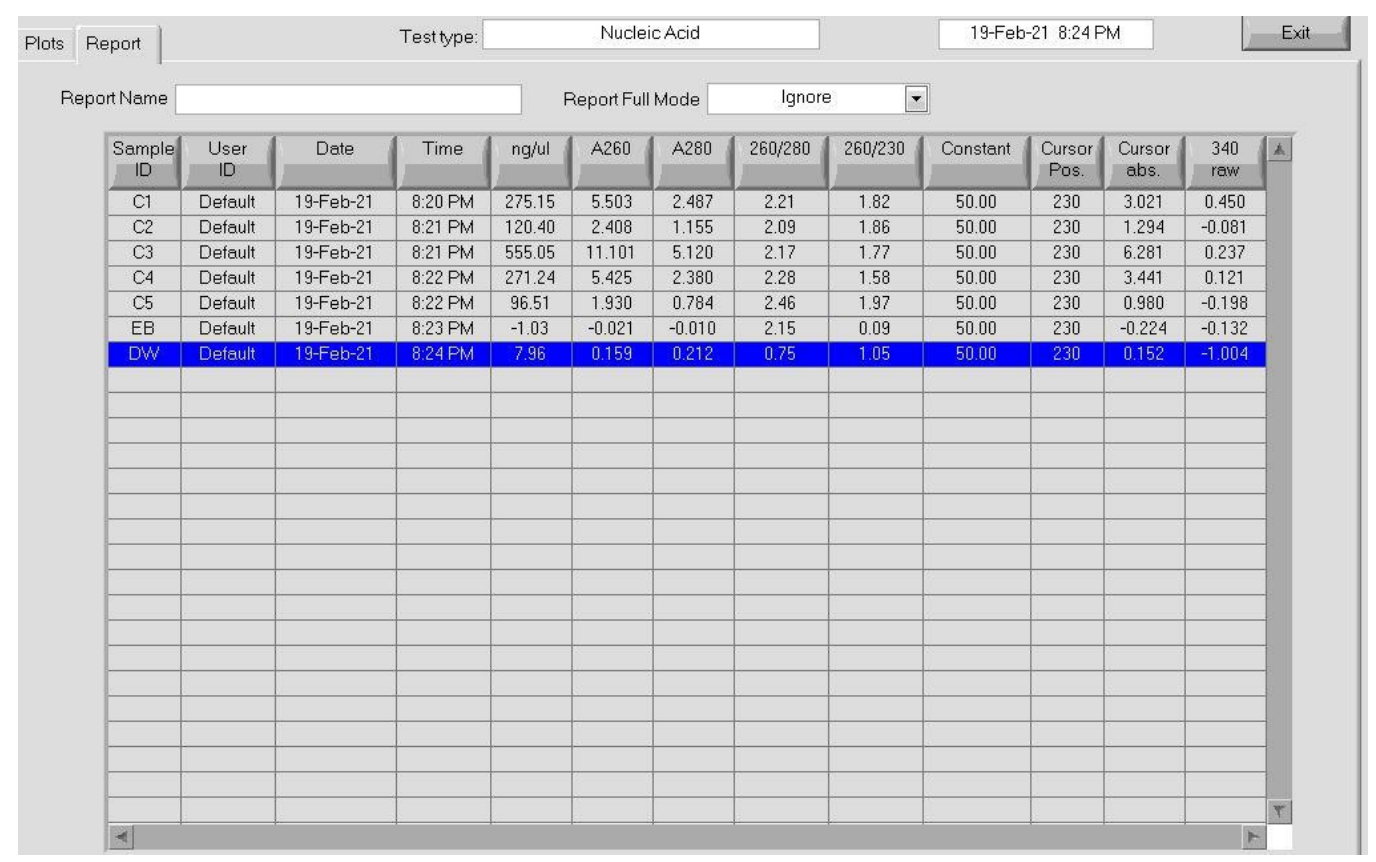

Fig.2. DNA Quantification figures on Nano 1000 (ng/ $\mu \mathrm{l})$ 


\section{Results From Agarose Gel Electrophoresis}

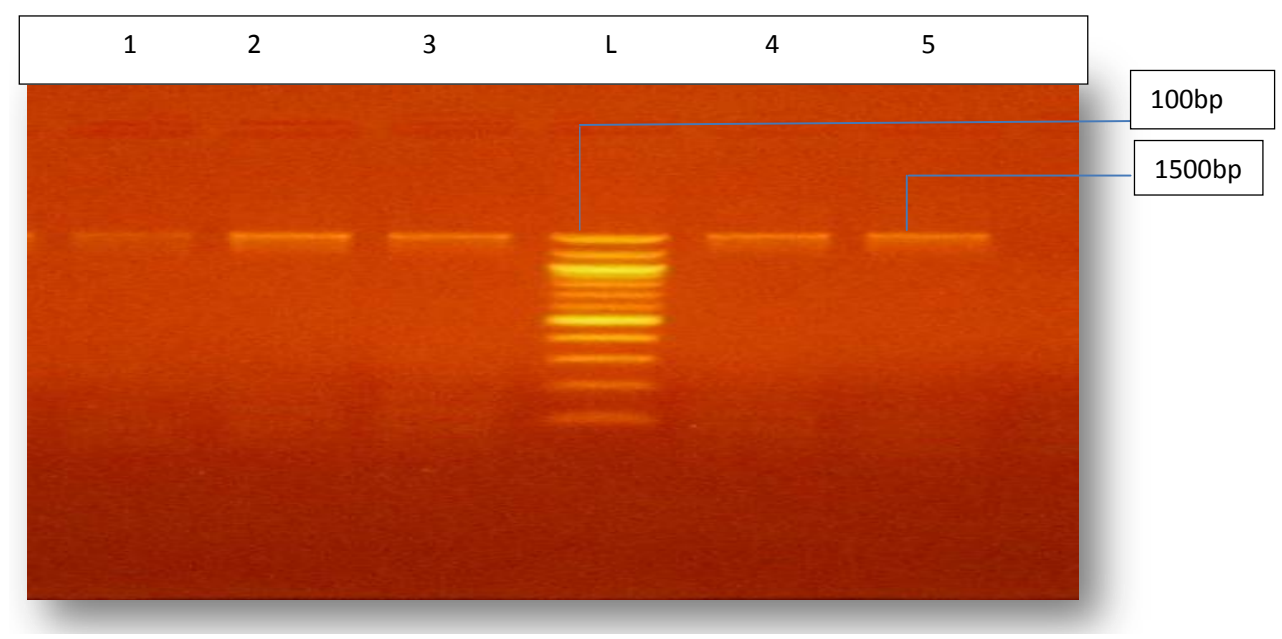

Fig.3. Agarose gel electrophoresis of some selected bacterial isolates. Lane 1,2,3,4 and 5 represents 16SrRNA gene bands (1500bp). Lane L represents the 100bp Molecular ladder

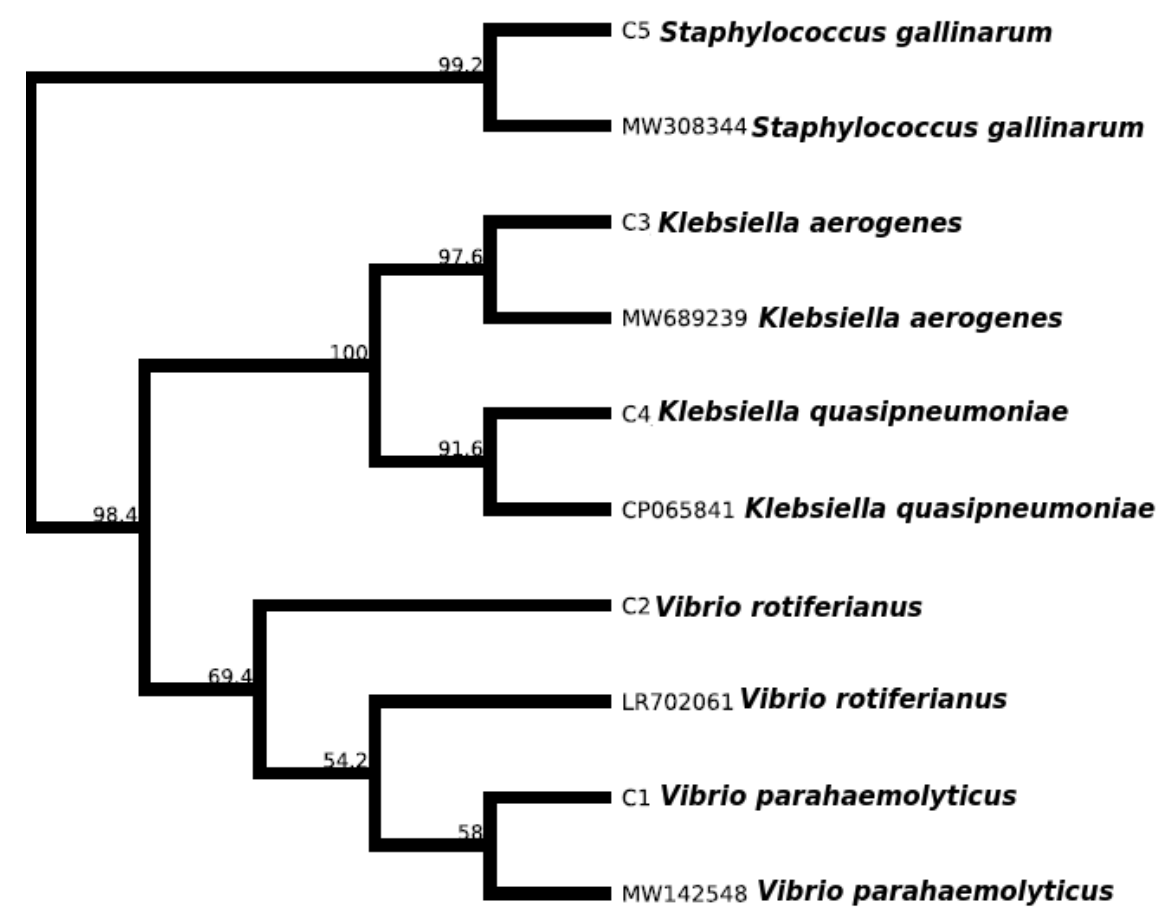

Fig.4. Evolutionary Distances between the Bacterial Isolates

\section{Discussion}

A total of 200 seafood samples were analyzed which produced $120(60 \%)$ pure isolates after characterization. Seafood samples harbour a consortium of microorganisms ranging from pathogenic microorganisms to normal commensals. The community of microorganisms found in a particular habitat is dependent on a number of factors such as composition, weather, pollution, location, time, etc. (Farmer III et al., 2005). Results obtained from this study showed that microorganisms of the genera Staphyococcus, Vibrio, and Klebsiella were present in the seafood sample. This corroborates the reports that seafoods harbour diverse groups of organisms such as Vibrios, Listeria, enteric virus etc (Papadopoulou et al., 2006). The growth of Staphylococcus and Klebsiella clearly shows that 
TCBS can indeed support the growth of other microorganisms other than Vibrio species. Out of the 120 pure cultures isolated, Vibrio species constitute $54.2 \%$ of the bacteria isolated while Klebsiella and Staphylococcus constitute $23.3 \%$ and $22.5 \%$ respectively. Staphylococcus species are not usually associated with marine environments but could perhaps be commensals in the sea-foods or the aquatic environment. The dominance of Vibrio species is evident of their normal commensals in seafood's (Cabanillas-Beltrán et al., 2006).The presence of Klebsiella species could be attributed to the activities around the environment such as sewage and other effluent discharged into the water body from the communities (Dib et al., 2014).

The analysis of variance (Anova) carried out shows that though the samples contain different isolates and different colony count, there is still no significant difference between the isolates in the samples as $\mathrm{p}>0.05$.

Staphylococcus gallinarum has been reported to be isolated from saliva of healthy humans, chicken, septic, and traumatic wounds of hospitalized patients (Ohara-Nemoto et al., 2008). It has also been isolated from blood cultures in patients with chronic hepatitis B infection thus its presence in seafood renders it unsafe for consumption. Its presence in the seafoods could be attributed to the human activities around the river banks where these seafoods are sold (Dib et al., 2014).

Vibrio rotiferanus was isolated from the seafood samples. This result corroborates the reports of Gomez-Bill et al. (2003) that isolated of V. rotiferianus from the rotifer culture (Brachionus plicatilis). Of all the bacterial species isolated, Vibrio parahaemolyticus was the most predominant and has been reported to be the top causative agent of food poisoning in Africa (Adeleye et al., 2010).

The result obtained from this study with regards to the high contamination by $V$. parahaemolyticus in these seafoods was in tandem with the reports of Vincent et al., (2015). The source of contamination could be from the water body, handlers of the seafoods or even as a result of the unhealthy practices by the people living around the river banks. V. parahaemolyticus is the major cause of food borne infection and its presence in food calls for urgent surveillance of contaminants in seafoods in order to ensure public health safety.

Klebsiella sp have been implicated in seafood samples due to the anthropogenic activities around the river banks as well as domestic activities by inhabitants of these areas. K. quasipneumoniae has been reported to be an opportunistic pathogen (Imai et al., 2019). However, its presence in the seafood can be considered dangerous since it has been also implicated in clinical infections in humans as an opportunistic pathogen (Imai et al., 2019).

The characterization of the isolates was done by PCR using 16srRNA as a target gene and all isolates possess the $16 \mathrm{srRNA}$ at $1500 \mathrm{bp}$. The sequenced isolates has revolutionary relationship with Staphylococcus gallinarum, Klebsiella quasipneumoniae, Klebsiella aerogenes, Vibrio parahaemolyticus and Vibrio rotiferianus with 100\% relatedness.

\section{Conclusion and Recommendation}

Although Staphylococcus gallinarum has not been reported to be implicated in food-borne infections or poisoning, the result of this study calls for a concern since the organism has been reported to be opportunistic. Also, there is risk for transfer of virulent and antibiotic resistant genes between the coagulase positive Staphylococcus and the 


\section{AJAST}

Asian Journal of Applied Science and Technology (AJAST)

Volume 5, Issue 3, Pages 68-79, July-September 2021

coagulase negative Staphylococcal species as well as other bacterial isolates such as Vibrio species. Klebsiella species reported in this study have been implicated in clinical as well as food borne infections, therefore, this calls for more investigative procedures to determine its presence in sea foods as well as proper handling of food by food handlers.

Vibrio species have been reported to be present in seafood as commensals and pathogens, however, new species are been implicated and this is of great concern as this could lead to the emergence of novel pathogenic strains which may lead to a global pandemic in the nearest future.

Health institutions and food processing firms should ensure food hygiene practices as well as proper food handling by food vendors. Public enlightenment on the need for proper cooking of food before consumption should be carried out especially in the rural areas of Southern Nigeria.

Consumption of raw sea foods such as Crab and Periwinkle by the Ijaws of the Niger Delta extraction should be strongly discouraged.

\section{Declarations}

\section{Source of Funding}

This research did not receive any grant from funding agencies in the public, commercial, or not-for-profit sectors.

\section{Competing Interests Statement}

The authors declare no competing financial, professional and personal interests.

\section{Ethical Approval}

Ethical approval for this research was given based on institutional guidelines.

\section{Consent for publication}

Authors declare that they consented for the publication of this research work.

\section{Availability of data and material}

Authors are willing to share the data and material according to relevant needs.

\section{References}

Adeleye, I.A., Daniels F.V. and Enyinnia, V.A. (2010). Characterization and Pathogenicity of Vibrio Spp. Contaminating Seafoods In Lagos, Nigeria. International Journal of Food Safety 12: 1-9.

Arungiri, K., Sivakumar, T. \& Murugan, T. (2016). Study of Vibrio species and its occurrence in seafood samples. Asian. Journal of Phamaceutical and Clinical Research 9(1): 229-231.

Brisse, S., Fevre, C., Passet, V., Issenhuth-Jeanjean, S., Tournebize, R., Diancourt, L. \& Grimont, P. (2009). Virulent clones of Klebsiella pneumoniae: identification and evolutionary scenario based on genomic and phenotypic characterization. PLoS ONE 4: 4982. 
Asian Journal of Applied Science and Technology (AJAST)

Volume 5, Issue 3, Pages 68-79, July-September 2021

Brisse, S. \& Verhoef, J. (2001). Phylogenetic diversity of Klebsiella pneumoniae and Klebsiella oxytoca clinical isolates revealed by randomly amplified polymorphic DNA, gyrA and parC genes sequencing and automated ribotyping. International Journal for Systemic Evolutionary Microbiology 51: 915-924.

Cabanillas, H, Lausás, E, Romero, R, Espinoza, A, García, A. \& Nishibuchi, M. (2006). Outbreak of gastroenteritis caused by the pandemic Vibrio parahaemolyticus O3:K6 in Mexico. FEMS Microbiology Letters 265: 76-80.

Dib, A. L., Lakhdara, N., Rodriguez, E.E., Kabouia, R., Roldán, E.M., Miguel Espigares García, M. E., Koutchoukali, H., Guerraichi, L. and Bouaziz, O. (2014). Prevalence of microbial contamination of fresh seafood product sold in Constantine, Algeria. International Academy of Ecology and Environmental Sciences 3(4): 83-87.

Farmer III, J.J., Janda, M., Brenner, F.W., Cameron, D.N., Birkhead, K. M., Genus, I. and Vibrio, P. (2005). 411AL. In: Brenner, D.J., Krieg, N.R., Staley, J.T. editors. Bergey’s Manual of Systematic Bacteriology. The Proteobacteria. Part B. The Gamma proteobacteria. 2nd ed. New York: Springer 2: 494-546.

Gomez-Gil, B., Thompson, F. L., Thompson, C. C. and Swings, J. (2003). Vibrio rotiferianus sp. nov., isolated from cultures of the rotifer Brachionus plicatilis. International Journal of Systematic and Evolutionary Microbiology 53: 239-243.

Holt, K.E., Wertheim, H., Zadoks, R.N., Baker, S., Whitehouse, C.A. \& Dance, D. (2015). Genomic analysis of diversity, population structure, virulence, and antimicrobial resistance in Klebsiella pneumoniae, an urgent threat to public health. Proceedings of National Academy of Science 112(27): 3574-3581.

Imai, K, Ishibashi, N, Kodana, M, Tarumoto, N, Sakai J., Kawamura T, Takeuchi, S, Taji, Y, Ebihara, Y, Ikebuchi, K, Murakami, T, Maesaki, S. (2019) Clinical characteristics in blood stream infections caused by Klebsiella pneumoniae, Klebsiella variicola, and Klebsiella quasipneumoniae: a comparative study BMC Inf. Dis.19: 94.

Kérouanton, A., Hennekinne, J.A., Letertre, C., Petit, L., Chesneau, O., Brisabois, \& De Buyser, M.L. (2007). Characterization of Staphylococcus aureus strains associated with food poisoning outbreaks in France. International Journal of Food Microbiology 115: 369-375.

Monica Cheesbrough (2006). District Laboratory Practice in Tropical Countries, Part 2, $2^{\text {nd }}$ Edition.

Omoe, K., Dong-Liang, H., Takahashi-Omoe, H., Nakane, A. \& Shinagawa, K. (2005). Comprehensive analysis of classical and newly described staphylococcal superantigenic toxin genes in Staphylococcus aureus isolates. FEMS Microbiology Letters 246: 191-198.

Ohara-Nemoto, Y., Haraga, H., Kimura, S. \& Nemato, T. K. (2008). Occurrence of Staphylococci in the oral cavities of healthy adults and nasal-oral trafficking of the bacteria. Journal of Medical Microbiology 57: 95-99.

Papadopoulou, C., Economou, E., Zakas, G., Salamoura, C., Dontorou, C and Apostolou, J. (2007). Micro biological and Pathogenic Contaminants of Seafood in Greece. Journal of Food Quality 30: 28-42.

Shon, A. S., Bajwa, R. P. \& Russo, T. A. (2013). Hypervirulent (hypermucoviscous) Klebsiella pneumoniae: a new and dangerous breed. Virulence 4: 107-118. 
Tamura, K., Peterson, D., Peterson, N., Strecher, G. and Kumar, S. (2013). Molecular Evolutionary Genetic Analysis Version 6.0. Molecular Biology and Evolution 30, (12): 2725-2729.

Tibra, N.K., Jalali, S., Reddy, A.K., Narayanan, R. \& Agarwal, R. (2010).Traumatic endophthalmitis caused by Staphylococcus gallinarum. Journal of Medical Microbiology 59: 365-366.

Ryan, P. (2007). Benthic communitues. Te Ara. The encyclopedia of New Zealand.

Shicongo-Nambabi, M.N.M., Petrus, N.P \& Schneider, M.B. (2012). The role, isolation and identification of Vibrio species on the quality and safety of seafood. Biotechnology and Molecular Biology Review 7(2): 16-30.

Vincent, M., Chan, C. S. W. and Apun, K. (2015). Molecular confirmation and characterization of Vibrio parahaemolyticus from retailed fish. International Food Research Journal 22(4): 1705-1710.

Xu, Z., Shah, H. N., Misra, R., Chen, J., Zhang,W., Liu, Y. \& Mkrtchyan, H. V. (2018). The prevalence, antibiotic resistance and mecA characterization of coagulase negative staphylococci recovered from non-healthcare settings in London, UK. Antimicrobial Resistance \& Infection Control 7(1): 73.

Zhang, X.H. \& Austin, B. (2005). Haemolysins in Vibrio species. Journal of Applied Microbiology 98(5): 1011-1019. 